\title{
PERILAKU KOROSI ATMOSFER BAJA GALVANIS SETELAH EKSPOS SINGKAT DI PELABUHAN RATU, JAWA BARAT
}

\author{
ATMOSPHERIC CORROSION BEHAVIOR OF GALVANIC STEEL \\ AFTER SHORT EXPOSURE IN PELABUHAN RATU, WEST JAVA)
}

\author{
Gadang Priyotomo $^{1 *}$, Siska Prifiharni ${ }^{1}$, Lutviasari Nuraini ${ }^{1}$, Ahmad Royani $^{1}$, Sundjono $^{1}$, dan \\ Hadi Gunawan ${ }^{2}$ \\ ${ }^{1}$ Pusat Penelitian Metalurgi dan Material, Lembaga Ilmu Pengetahuan Indonesia \\ Kawasan PUSPIPTEK, Gd.470, Tangerang Selatan, Banten,15314, Indonesia \\ ${ }^{2}$ Pusat Penelitian dan Pengembangan Jalan dan Jembatan, Kem. Pekerjaan Umum dan Perumahan Rakyat \\ ${ }^{1, *}$ E-mail: gadangpriyotomo@yahoo.com
}

\begin{tabular}{|c|c|}
\hline ARTICLE INFO & Abstract \\
\hline $\begin{array}{l}\text { Article history } \\
\text { Received date: } \\
\text { 2019-03-20 } \\
\text { Received in revised form date: } \\
\text { 2019-06-21 } \\
\text { Accepted date: } \\
\text { 2019-06-24 } \\
\text { Available online date: } \\
\text { Juli } 2019\end{array}$ & $\begin{array}{l}\text { A study of atmospheric corrosion for galvanic steels had been perfomed in } \\
\text { coastal area of Pelabuhan Ratu, West Java Province, in which arranged } \\
\text { exposure time up to } 76 \text { days. The performance of their corrosion resistance } \\
\text { was determined with loss weight method. Surface morphology, elemental } \\
\text { compositions and phases for oxide products of observed galvanized coating } \\
\text { was carry out using scanning electron microscope (SEM), energy dispersive } \\
\text { spectroscopy (EDS) and X-ray diffraction (XRD) respectively. Enviromental } \\
\text { factors which influence corrosion behavior were monitored during exposure } \\
\text { such as relative humidity, air temperature, dew temperature and airborne } \\
\text { salinity. On the basis of results, values of corrosion rate were } 0.64 \text { mpy at } \\
27 \text { days exposure and } 0.12 \text { mpy at } 76 \text { days. Prediction of service life for } \\
\text { zinc coating on steel substract is } 18 \text { years. The combination of alternate wet } \\
\text { and dry was followed by fluctuated relative humidity and air temperature } \\
\text { created protective dull grayed layer in increasing time exposure. However, } \\
\text { the presence of chloride has less role as corrosion reaction accelerator due } \\
\text { to lower airborne salinity during exposures. Phases of zinc coating are } \\
\text { zincite (ZnO) dan hydrozincite (Zn }{ }_{5} \text { (CO3). }{ }_{2} \text {. (OH) }{ }_{6} \text { ), in which the layers were } \\
\text { protected for further corrosion attack. } \\
\text { Keywords: Atmospheric corrosion, Galvanic corrosion, Chloride, Relative } \\
\text { humidity, Tropical marine }\end{array}$ \\
\hline
\end{tabular}

Kata kunci:

Korosi atmosfer

Baja galvanis

Klorida

Kelembapan relatif

Laut tropis

\begin{abstract}
Abstrak
Studi korosi atmosfer baja galvanis dilakukan di daerah pantai Pelabuhan Ratu, Jawa Barat, yang diatur waktu ekspos hingga 76 hari. Perfoma ketahanan korosinya ditentukan dengan metode kehilangan berat. Morfologi permukaan, komposisi unsur, dan senyawa produk korosi baja galvanis diamati dengan menggunakan scanning electron microscope (SEM), energy dispersive spectroscopy (EDS), dan X-Ray diffraction (XRD). Faktor lingkungan udara yang memengaruhi proses korosi dimonitoring selama ekspos antara lain kelembapan relatif, suhu udara, suhu embun, dan salinitas udara. Berdasarkan hasil, nilai laju korosi material adalah 0,64 mpy di waktu ekspos 27 hari dan 0,12 mpy di 76 hari. Prediksi umur pakai lapisan seng baja galvanis adalah 18 tahun. Kombinasi waktu basah dan kering bergantian ditandai dengan fluktuasi kelembapan udara dan suhu menciptakan lapisan protektif kusam dan kelabu seiring peningkatan waktu ekspos. Keberadaan klorida sebagai pemercepat reaksi korosi kurang berperan, dikarenakan kadar salinitas yang kecil. Fase produk lapisan seng adalah zincite ( $\mathrm{ZnO})$ dan hydrozincite $\left(\mathrm{Zn}_{5}\left(\mathrm{CO}_{3}\right)_{2} .(\mathrm{OH})_{6}\right)$ dimana lapisan tersebut sangat protektif untuk serangan korosi berlanjut.
\end{abstract}




\section{PENDAHULUAN}

Korosi atmosfer logam merupakan suatu proses elektrokimia dimana proses basah dan kering secara simultan terjadi ketika lapisan elektrolit terbentuk di permukaan logam (Jenifer Alcántara, Daniel de la Fuente, Belén Chico, Joaquín Simancas 2017). Umumnya, persentase kerusakan infrastruktur logam akibat korosi atmosfer hingga 80\% (Badea, G.E., P. Cret, M. Lolea 2011). Oleh karena itu, pengaruh atmosfer terhadap struktur logam menjadi masalah besar di bidang korosi. Lebih jauh lagi, korosi atmosfer logam sangat kompleks untuk diinvestigasi dikarenakan banyak parameter lingkungan yang dipertimbangkan sehingga mendapatkan data yang valid. Salah satu parameter lingkungan penting yang dipertimbangkan adalah pengendapan air (hujan dan kabut) dan kelembapan relatif yang tinggi, dimana meningkatkan laju korosi logam baja di atmosfer (Manuel Morcillo, Jenifer Alcántara, Iván Díaz, Belén Chico, Joaquín Simancas 2015). Kerentanan korosi atmosfer tergantung dari lokasi lingkungan antara lain pedalaman (rural), perkotaan (urban), industri, dan laut. Salah satu faktor lingkungan yang utama adalah keberadaan polutan, dimana terdapat senyawa garam klorida di daerah laut dan senyawa sulfur di industri (Roberge 1999). Faktor temperatur udara juga memengaruhi kondisi kebasahan permukaan logam, dimana peningkatan temperatur mengurangi efek kebasahan (John Onan Onyatta, Amir Okeyo Yusuf 2016). Parameter lingkungan yang memengaruhi nilai laju korosi logam dengan pertimbangan letak geografis dan iklim daerah memberikan alasan bahwa pengujian lapangan lebih cenderung dilakukan dibandingkan pengujian simulasi skala laboratorium.

Kerentanan korosi atmosfer terhadap struktur baja di lingkungan pantai telah diinvestigasi oleh banyak peneliti, di- mana degradasi logam sangat signifikan (Castro-Borges, P., Veleva 2015; Feliu, S., Morcillo, M., Chico 1999; Jaen, J.A., Iglesias, J., Hernandez 2012; Jaen, J.A., Munoz, A., Justavino 2009). Beberapa metode pengendalian dan perlindungan logam struktur di atmosfer adalah lapis lindung cat dan lapis lindung seng. Keunggulan lapis lindung seng adalah efek perlindungan katodik seng terhadap baja, dimana kerusakan lapis seng tidak mengganggu proses perlindungannya. Kerusakan lapis lindung cat akan memberikan efek kerusakan lebih pada substrak baja. Di Indonesia, efek perlindungan lapis seng dengan baja galvanis berkontribusi menurunkan laju korosi hingga 20 kali dibandingkan baja struktur di daerah Limbangan, Indramayu, Jawa Barat, dimana efek klorida memengaruhi kinerja lapis lindung (Nuraini, L., Prifiharni, S., Priyotomo, G., Sundjono, Gunawan, H. 2018). Penurunan laju korosi suatu logam struktur secara langsung memberikan dampak umur pakai struktur semakin panjang. Di sisi lain, waktu ekspos paparan juga memberikan perilaku ketahanan terhadap logam struktur di daerah pantai (Jaen, J.A., Iglesias, J., Hernandez 2012).

Di sisi lain, sehubungan dengan perfoma ketahanan baja galvanis di daerah pantai, penelitian ini belum sepenuhnya dilakukan di berbagai daerah di pulau Jawa khususnya di daerah pantai selatan, dimana faktor geografis memberikan kontribusi berbeda terhadap degradasi material dibandingkan dengan penelitian di daerah Indramayu (Nuraini, L., Prifiharni, S., Priyotomo, G., Sundjono, Gunawan, H. 2018). Perbedaan faktor letak geografis memengaruhi kondisi atmosfer antara lain kelembapan relatif dan salinititas udara. Pantai di utara jawa memiliki iklim kering dengan dataran rendah, dimana pantai di selatan jawa memiliki iklim lembap dengan dataran tinggi (Subarna 2019). 
Iklim kering dihubungkan dengan kelembapan yang cenderung rendah, dibandingkan iklim basah. Iklim kering dengan curah hujan rendah meningkatkan salinitas dan sebaliknya (Md Mukhlesur Rahman, Mohitul Ameen Ahmed Mustafi, A.F.M.T. Islam 2015).

Salah satu lokasi riset ini adalah di daerah pantai Pelabuhan Ratu, Jawa Barat. Tujuan penelitian ini untuk menjelaskan perilaku kerusakan korosi atmosfer baja galvanis dan mekanismenya setelah melalui paparan dengan waktu ekpos tertentu di lingkungan pantai bertipikal tropis.

\section{METODE}

\section{Preparasi Spesimen dan Karakterisasi Sebelum Ekspos}

Baja galvanis berbentuk pelat dipersiapkan dalam peneliti ini. Logam tersebut dipotong untuk dibentuk menjadi pelat berdimensi $15 \mathrm{~cm} \times 7,5 \mathrm{~cm}$ dengan ketebalan $3 \mathrm{~mm}$. Pembersihan spesimen baja galvanis merujuk pada standar ASTM G-1, kemudian disimpan dalan wadah desikator vakum. Dalam pemasangan spesimen uji, hanya permukaan atas yang terekspos dan permukaan bawah ditutup dengan lapisan lakban hitam. Pemasangan spesimen uji dilakukan di rak uji lapangan yang terlihat pada Gambar 1b. Posisi spesimen terpasang adalah $45^{\circ}$ terhadap posisi horisontal dan dihadapkan ke arah pantai. Verifikasi dan validasi spesimen baja galvanis dilakukan untuk melihat kesesuaian standar galvanized coating grade ASTM A123-00. Langkah verifikasi antara lain pengukuran ketebalan subtrak baja dan ketebalan lapis seng sebelum ekspos dengan menggunakan alat mikroskop optik metalurgi, model MT7100, Meiji, Jepang. Sampel uji dipotong melintang serta verifikasi lainnya adalah karakterisasi struktur mikro lapis seng dengan metode metalografi dan komposisi unsur-unsur lapis seng, dimana menggunakan juga alat mikroskop yang sama.

\section{Lokasi Penempatan Spesimen di Lapangan}

Pemasangan sampel uji dilakukan di jembatan Cidahon, terletak 200 meter dari bibir pantai daerah Pelabuhan Ratu, Jawa Barat yang terlihat pada Gambar 1a. Pengukuran endapan salinitas udara (airborne salinity) dilakukan dengan meletakan bingkai kayu $10 \mathrm{~cm}$ x $10 \mathrm{~cm}$ yang berisi kain kasa. Uap garam di udara akan terperangkap di kain kasa. Pengukuran suhu udara, suhu embun, dan kelembapan udara dengan menggunakan digital hygrometer thermomete data logger 21000 Record Meter UK B0211, Inggris terpasang di rak uji.

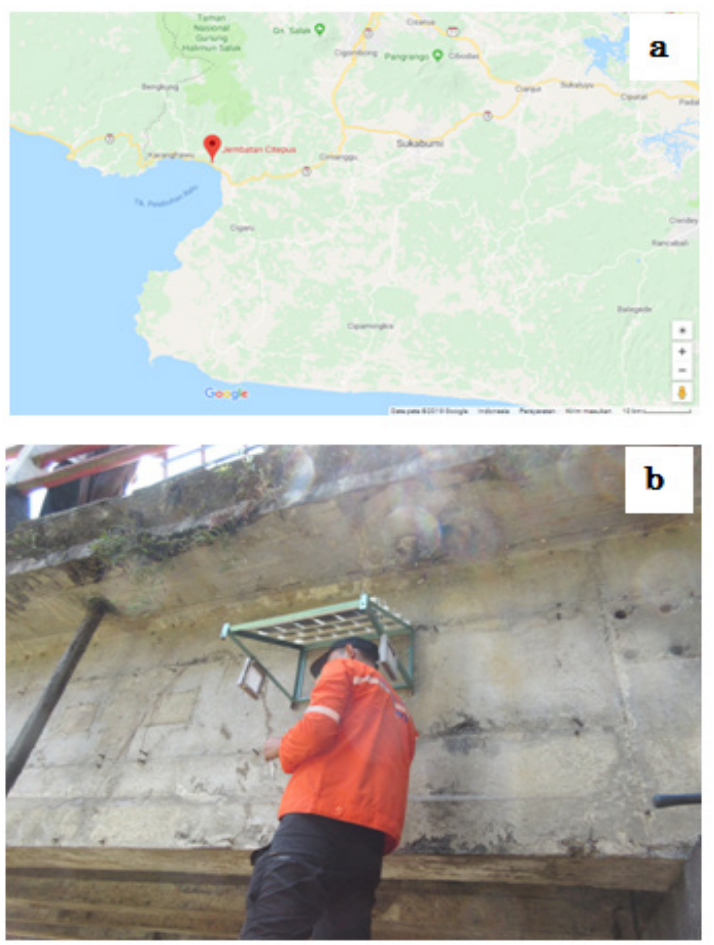

Gambar 1. a) Lokasi pemasangan rak uji di jembatan Cidahon, Pelabuhan ratu, Jawa Barat; b) Pemasangan rak uji di jembatan.

Pengambilan spesimen, kain kasa dan, data kelembapan dan suhu dilakukan pada interval 27 dan 76 hari. Penentuan interval 
waktu uji merupakan faktor yang penting untuk melihat inisiasi proses elektrokimia suatu logam pada hari ke-27 dan kemungkinan pembentukan lapisan pasif protektif di permukaan baja galvanis pada hari ke-76. Pengukuran kadar salinitas udara dilakukan dengan mencuci kain kasa sehingga garam larut, kemudian diukur dengan menggunakan chloride titrator strips kit merek HACH, Amerika Serikat.

\section{Karakterisasi dan Analisis Spesimen Uji Setelah Ekspos}

Setiap periode ekspos, spesimen uji diambil dari rak uji dan dianalisis di laboratorium. Spesimen dibersihkan, di-pickling untuk dibuang semua produk korosi di permukaan spesimen yang mengacu pada standar ASTM G1. Nilai laju korosi setiap spesimen diperhitungkan dengan metode kehilangan berat, dimana perhitungan dilakukan dengan pengukuran berat sebelum ekspos dan sesudah ekspos. Persamaan laju korosi terlihat di bawah ini.

$$
\mathrm{LK}=\frac{\Delta \mathrm{W} \cdot \mathrm{K}}{\mathrm{d} \cdot \mathrm{A} \cdot \mathrm{t}}
$$

dimana:

LK = Laju Korosi dalam mills per year (mpy);

$=$ kehilangan berat dalam gram;

$\mathrm{K}=$ Konstanta;

$\mathrm{d}=$ densitas logam dalam $\mathrm{g} / \mathrm{cm}^{3}$;

$\mathrm{t}=$ waktu ekspos (hari)

Morfologi permukaan karat secara makro dan mikro menggunakan alat kamera Canon Ixus 185, Jepang dan scanning electron microscope (SEM), merek JEOL JED-2300, Jepang. Produk korosi lapisan baja galvanis juga diidentifikasi secara unsur dengan menggunakan energy dispersive spectroscopy (EDS) melalui alat SEM yang sama dan senyawa produk dengan $X$-ray diffraction (XRD) Rigaku tipe SmartLab 3 kW, Jepang.

\section{HASIL DAN PEMBAHASAN Karakterisasi Spesimen Uji Sebelum Ekspos}

Karakterisasi spesimen uji baja galvanis sebelum ekspos adalah bagian dari verifikasi dan validasi grade baja saat diterima. Gambar 2 memperlihatkan baja galvanis sebelum ekspos, dimana kondisi lapisan masih mengilat dan cemerlang. Umumnya, baja galvanis baru terdapat pola spangle, yang merupakan pola kristalisasi dendrit yang menyebar. Ada dan tidak ada pola spangle tidak memengaruhi perfoma lapisan dalam melindungi baja dari korosi luar.

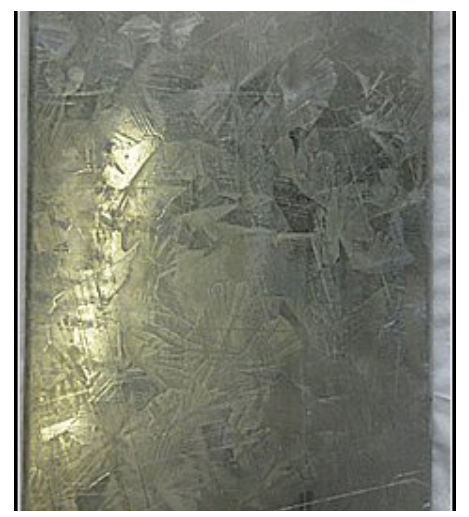

Gambar 2. Foto makro sampel uji baja galvanis sebelum ekspos di Pelabuhan Ratu

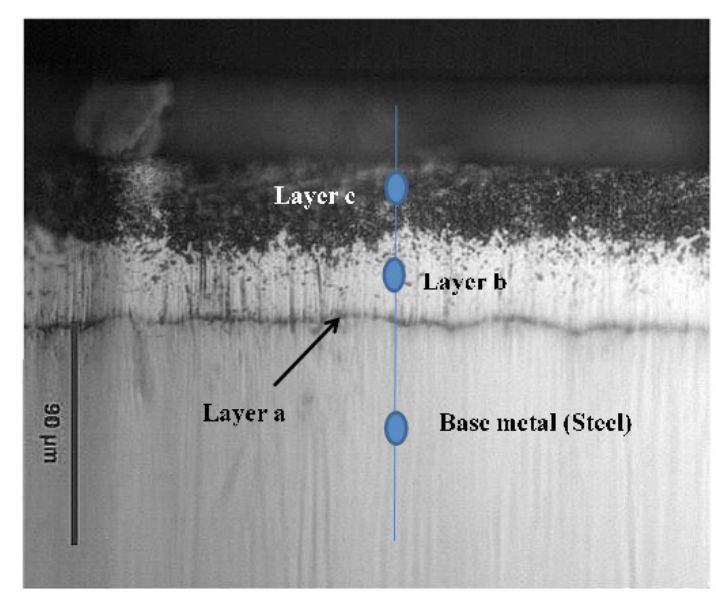

Gambar 3. Mikrostruktur baja galvanis yang dipotong melintang sebelum ekspos 
Gambar 3 memperlihatkan mikrostruktur baja galvanis yang dipotong melintang sebelum ekspos, dimana berbagai fase logam terdapat di lapisan seng. Pada hasil karakterisasi logam, fase-fase logam di lapisan seng terlihat pada Tabel 1, yang disesuaikan dengan fase-fase lapisan seng (Stephen R. Yeomans 2004).

Tabel 1. Fase-fase logam di lapisan seng baja

\begin{tabular}{ccl} 
No & Daerah & \multicolumn{1}{c}{ Keterangan } \\
\hline 1 & Base metal & Subtrak logam baja (Fe) \\
2 & Layer a & $\begin{array}{l}\text { Fase Gamma (paduan Fe dan } \\
\text { Zn) }\end{array}$ \\
3 & Layer b & $\begin{array}{l}\text { Fase delta dan Zeta (paduan } \\
\text { Fe dan Zn) }\end{array}$ \\
4 & Layer c & Fase Eta (Zn murni) \\
\hline
\end{tabular}

Verifikasi tipe atau grade baja galvanis sebagai sampel uji dilakukan dengan mengacu standar ASTM A123. Ketebalan rata-rata lapisan seng adalah $56,4 \mu \mathrm{m}$, dimana ketebalan subtrak baja adalah 2,1 $\mathrm{mm}$. Grade atau tipe baja galvanis sebagai sampel uji adalah G55 (ASTM A123), yang mempunyai ketebalan minimal $55 \mu \mathrm{m}$ atau berat per area $390 \mathrm{gr} / \mathrm{m}^{2}$. Salah satu parameter prediksi umur pakai lapisan seng adalah nilai ketebalan lapisan seng, dimana umur pakai lapisan semakin panjang dengan semakin tebalnya lapisan seng. Umur lapisan galvanis semakin turun seiring dengan agresivitas lingkungan atmosfer. Daerah laut lebih agresif dibandingkan daerah urban dan rural. Ketebalan lapisan seng spesimen $56,4 \mu \mathrm{m}(2,2$ mills $)$ diprediksi memiliki nilai umur pakai hingga 25 tahun di lingkungan laut tropis dan 70 tahun di lingkungan pedesaan (rural) (J.Langill. 2003).

\section{Laju Korosi dan Hubungannya Dengan Parameter Lingkungan}

Gambar 4 memperlihatkan nilai laju korosi baja galvanis sebagai fungsi waktu ekspos hingga 76 hari. Secara umum, laju korosi atmosfer baja galvanis cenderung turun lima kali seiring waktu ekspos 76 hari. Hasil kajian perfoma baja galvanis di daerah Limbangan, Indramayu memperlihatkan laju korosi hingga 0,16 mpy (Nuraini, L., Prifiharni, S., Priyotomo, G., Sundjono, Gunawan, H. 2018), dimana nilai laju korosi baja galvanis sekitar 0,12 mpy pada waktu ekspos 76 hari di Pelabuhan Ratu. Hasil salinitas udara rata-rata selama ekspos 76 hari sekitar 24,3 $\mathrm{mg} / \mathrm{m}^{2}$. hari di Pelabuhan Ratu, dimana di daerah Limbangan sekitar $117 \mathrm{mg} / \mathrm{m}^{2}$. hari (Nuraini, L., Prifiharni, S., Priyotomo, G., Sundjono, Gunawan, H. 2018). Lebih jauh lagi, di Pelabuhan Ratu, posisi lokasi uji dan bibir pantai sekitar 200 meter, sedangkan di Limbangan, sekitar 100 meter (Nuraini, L., Prifiharni, S., Priyotomo, G., Sundjono, Gunawan, H. 2018). Berdasarkan ISO 9223, klasifikasi daerah pesisir pantai (coastal region) yang agresif terjadinya kerusakan korosi logam, jika klasifikasi salinitas udara (SU) termasuk katagori S1 $(3<\mathrm{SU}<60) \mathrm{mg} / \mathrm{m}^{2}$. hari dan $\mathrm{S} 2(60<\mathrm{SU} 300) \mathrm{mg} / \mathrm{m}^{2}$.hari. Pada kedua lokasi sampel di pantai yang berbeda masih dikatagorikan daerah pesisir pantai meskipun berbeda jarak dari garis pantai.

Berdasarkan hasil laju korosi baja galvanis (0,12 mpy) hingga waktu ekspos 76 hari, prediksi umur pakai lapis seng adalah 18 tahun di daerah. (J.Langill. 2003) melaporkan bahwa prediksi umur pakai lapisan seng daerah udara laut tropis adalah 25 tahun. Indikasi perbedaan prediksi disebabkan beberapa faktor antara lain curah hujan, waktu basah dan kering, arah angin, faktor jarak lokasi uji ke pantai, dan lainnya. 


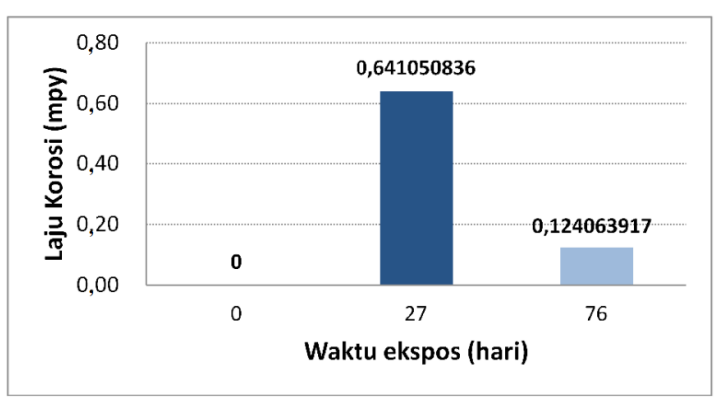

Gambar 4. Laju korosi baja galvanis sebagai fungsi waktu ekspos di Pelabuhan Ratu, Jawa Barat

Lebih jauh lagi, kerentanan korosi atmosfer tergantung lamanya waktu ekspos dan pengaruh lingkungan antara lain salinitas udara, kandungan sulfur, suhu udara, dan kelembapan udara (Feliu, S., Morcillo, M., Chico 1999). Kandungan sulfur umumnya terdapat di daerah industri. Pembahasan parameter salinitas udara telah dibahas di atas. Keberadaan lapisan elektrolit (lapisan berair tipis) terjadi di permukaan logam saat mencapai nilai kelembapan kritis (Roberge 1999) Di sisi lain, reaksi korosi mulai berjalan perlahan-lahan di lingkungan laut dengan nilai kelembapan kritis 60\% (CastroBorges, P., Veleva 2015) dan berjalan meningkat drastis direntang kelembapan relatif 75 s.d. $80 \%$ (Li, Z.W., Marston, N.J., Jones 2013). Gambar 5 memperlihatkan hubungan nilai kelembapan relatif, terpantau setiap jam dan direkam saat pemasangan, ekspos 27 dan 76 hari. Waktu awal dan akhir pengamatan kelembapan relatif adalah jam lima pagi. Nilai kelembapan relatif tinggi di rentang tengah malam dan awal pagi, sedangkan nilai menurun saat matahari muncul. Selama ekspos berlangsung, lebih dari $98 \%$ nilai kelembapan kritis terjadi di lokasi uji (garis putus-putus).
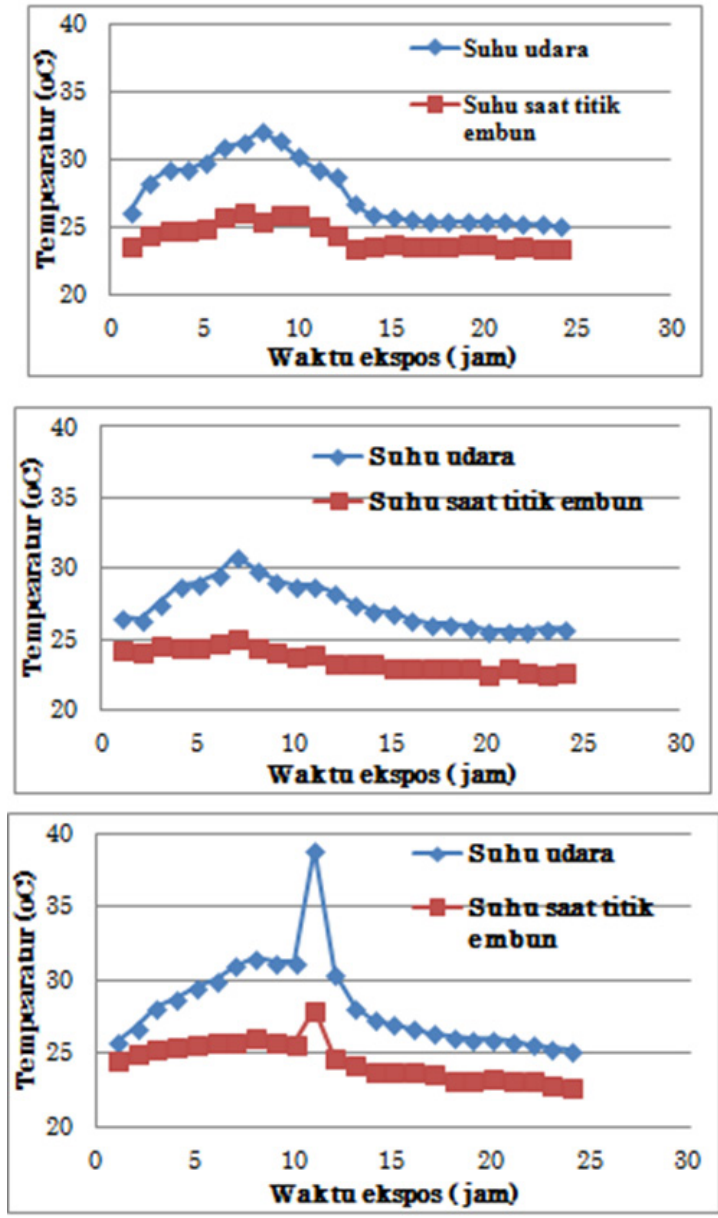

Gambar 6. Suhu udara dan suhu saat titik embun per jam di a) hari pertama ekspos; b) ekspos hari ke 27; dan c) ekspos hari ke 76

\section{Morfologi dan Karakterisasi Baja Galvanis setelah Ekspos}

Gambar 7 memperlihatkan kondisi permukaan baja galvanis setelah ekspos di lapangan. Setelah ekspos, perubahan visual permukaan terjadi, kondisi mengilat dan cerah saat sebelum ekspos (Gambar 2) serta kondisi pudar dan kelabu setelah ekspos. Hasil pengamatan visual lainnya bahwa pemudaran kondisi mengilat cenderung kelabu seiring dengan waktu ekspos hingga 76 hari, dimana bentuk spangled semakin samar. 


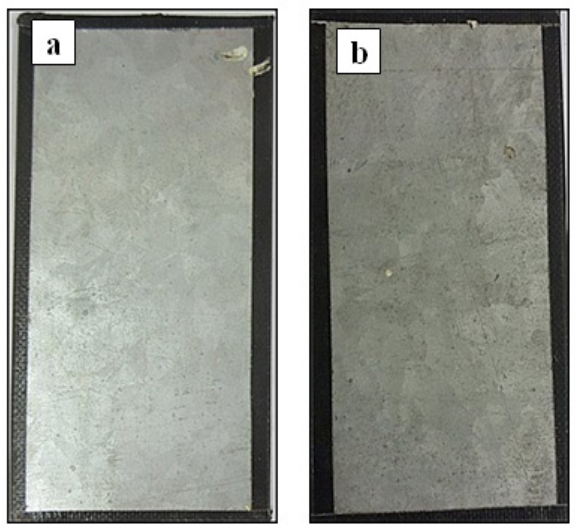

Gambar 7. Kondisi permukaan baja galvanis setelah ekspos di hari ke- a) 27 dan b) 76

Gambar 8 memperlihatkan morfologi melintang baja galvanis sebelum dan sesudah ekspos di lapangan. Kondisi lapisan seng pada baja galvanis sebelum ekspos memperlihatkan kondisi cerah dibandingkan substrak baja. Di sisi lain, setelah ekspos, kondisi lapisan seng berubah menjadi lebih gelap dibandingkan substrak baja. Kondisi permukaan lapis seng sebelum ekspos lebih halus dibandingkan sesudah ekspos.
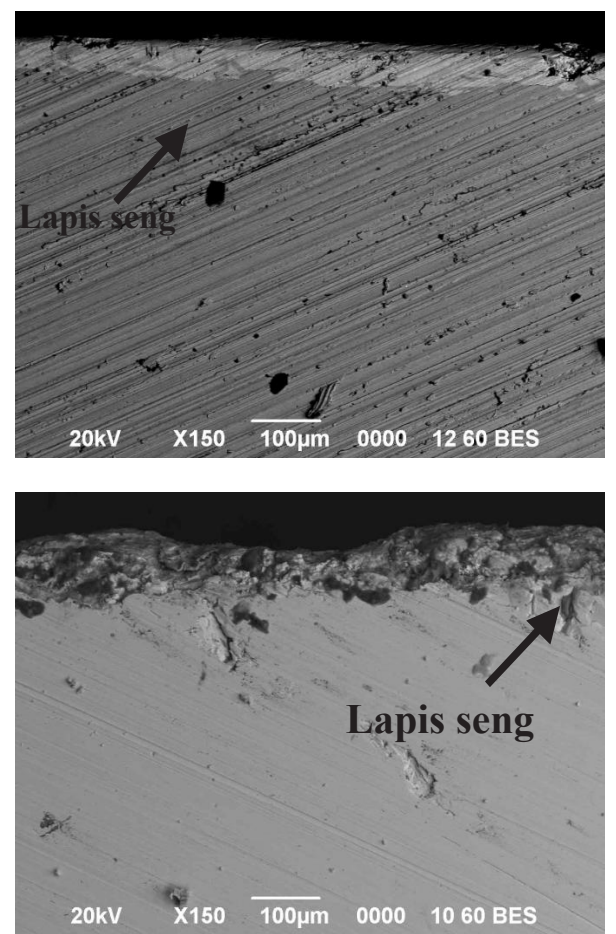

Gambar 8. Morfologi melintang baja galvanis sebelum dan sesudah ekspos di lapangan
Sebaran unsur-unsur baja galvanis sebelum dan sesudah ekspos selama 76 hari terlihat pada Gambar 9 dan 10. Kondisi sebelum ekspos, konsentrasi unsur seng (Zn) sangat tinggi di lapisan galvanis, dimana unsur oksigen sebagai bagian dari senyawa logam oksida tidak tinggi. Konsentrasi unsur besi $(\mathrm{Fe})$ terdistribusi rapat di subtrak baja, dimana unsur karbon (C) sangat kecil.
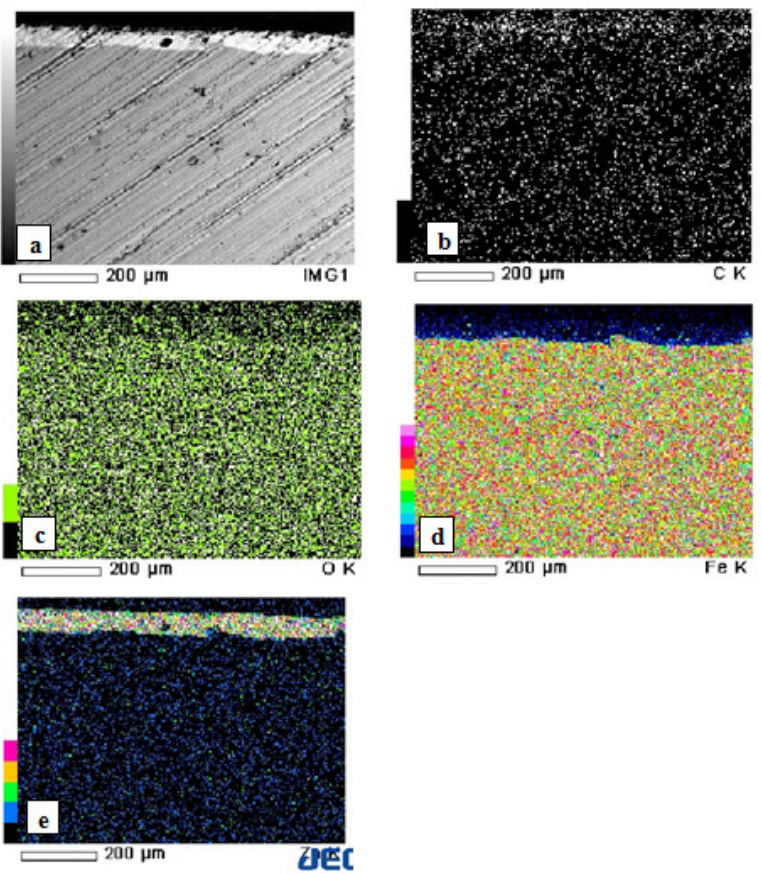

Gambar 9. Distribusi unsur-unsur a) SEM; b) C; c) $\mathrm{O}$; d) $\mathrm{Fe}$; dan e) Zn pada penampang melintang baja galvanis sebelum ekspos

Di sisi lain, kondisi setelah ekspos selama 76 hari, konsentrasi unsur Zn masih sangat tinggi di lapisan galvanis, dimana distribusi unsur oksigen mulai meningkat dibandingkan sebelum ekspos. Peningkatan distribusi oksigen pada lapisan galvanis terindikasi bahwa telah terbentuk senyawa logam oksida sebagai hasil reaksi elektrokimia dari lingkungan luar. Keberadaan klorida $(\mathrm{Cl})$ tersebar di lapisan galvanis mengindikasikan paparan uap garam yang terkuantifikasi dalam nilai salinitas udara. 

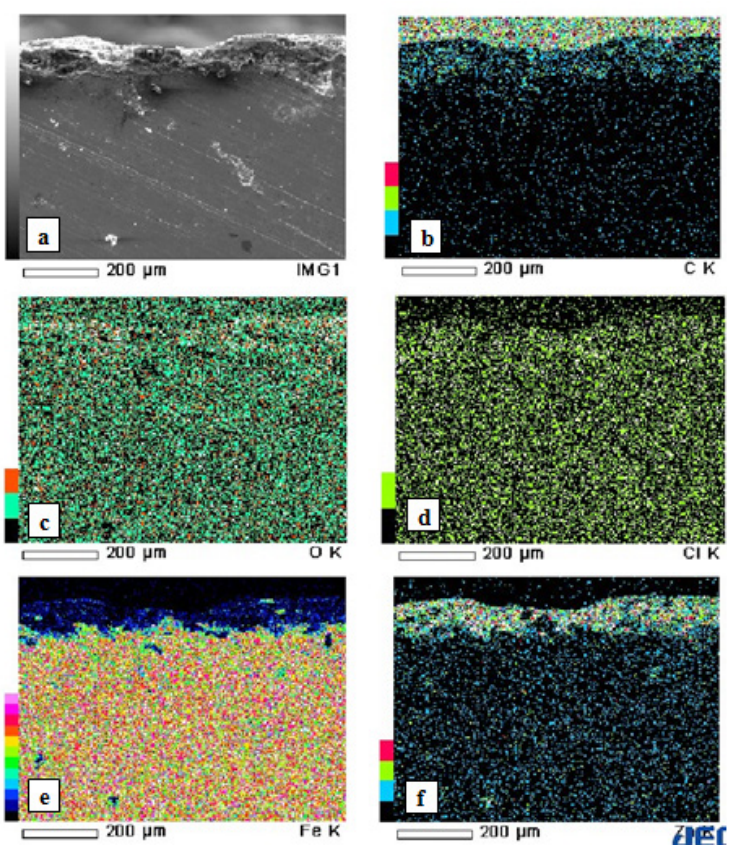

Gambar 10. Distribusi unsur-unsur a) SEM; b) C; c) $\mathrm{O}$; d) Fe; dan e) Zn pada penampang melintang baja galvanis setelah ekspos 76 hari.

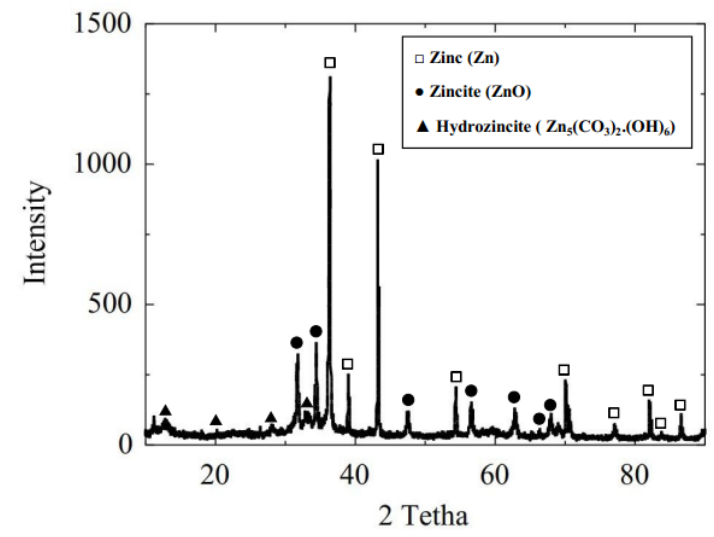

Gambar 11. Hasil XRD produk korosi baja galvanis setelah ekspos 76 hari

Peran ion klorida dari uap garam memengaruhi aktivitas reaksi elektrokimia saat kondisi basah di permukaan baja galvanis, dimana konduktivitas elektrolit meningkat (Ubuoh E, Nwakanma C 2017). Peningkatan konduktivitas elektrolit saat kondisi basah di permukaan logam mempercepat reaksi korosi, dimana tergantung dari kadar salinitas udara. Walaupun demikian, hasil karakterisasi produk korosi tidak memperlihatkan senyawa yang mengandung unsur klorida. Setelah ekspos selama 76 hari, Produk korosi di permukaan baja galvanis antara lain Seng ( $\mathrm{Zn})$, Zincite $(\mathrm{ZnO})$ dan hydrozincite $\left(\mathrm{Zn}_{5}\left(\mathrm{CO}_{3}\right)_{2} \cdot(\mathrm{OH})_{6}\right)$ yang terlihat pada Gambar 11. Pada umumnya, produk korosi di permukaan baja galvanis antara lain simonkolleite $\left(\mathrm{Zn}_{5}(\mathrm{OH})_{8} \mathrm{Cl}_{2} \cdot \mathrm{H}_{2} \mathrm{O}\right)$, hydrozincite $\left(\mathrm{Zn}_{5}\left(\mathrm{CO}_{3}\right)_{2}(\mathrm{OH})_{6}\right)$ and zinc $(\mathrm{Zn})$, dan sodium hydroxyl-chlorosulfate $\left(\mathrm{NaZn}_{4} \mathrm{Cl}(\mathrm{OH})_{6} \mathrm{SO}_{4} \cdot 6 \mathrm{H}_{2} \mathrm{O}\right)$ (Rosa Vera, Fabián Guerrero, Diana Delgado 2013). Senyawa zincite $(\mathrm{ZnO})$ terbentuk saat baja galvanis terekspos dengan adanya oksigen di udara, dimana karakter senyawa tersebut adalah rapat, kuat dan protektif terhadap korosi (Y.W. Liu, Z.Y. Wang, G.W. Cao, Y. Cao 2017). Keberadaan kelembapan tinggi dalam bentuk proses kondensasi membasahi permukaan logam, dimana bereaksi dengan zincite untuk membentuk seng hidroksida. Pada kondisi permukaan basah, keberadaan karbon dioksida di udara bereaksi membentuk hydrozincite yang protektif. Proses pembentukan lapisan seng stabil dan rapat hydrozincite melalui tahapan sebagai berikut.

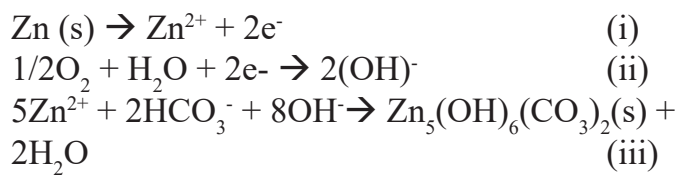

Keberadaan senyawa simonkolleite di lapisan galvanis tidak terdeteksi pada hasil $\mathrm{XRD}$, dimana umum senyawa tersebut terbentuk dengan salinitas udara tinggi di lingkungan laut (Rosa Vera, Fabián Guerrero, Diana Delgado 2013). Nilai salinitas udara yang tidak tinggi, kandungan ion klorida di lapisan galvanis dan faktor jarak yang cukup jauh antara bibir pantai dan lokasi uji memberikan indikasi tidak terbentuk secara jelas senyawa simonkolleite. Lebih jauh lagi, perubahan warna mengkilat lapisan galvanis sebelum ekspos menjadi kusam cenderung kelabu setelah ekspos 76 hari mengindikasikan pemben- 
tukan senyawa hydrozincite (Association 2010) dan zincite. Oleh karena itu pembentukan dua senyawa tersebut bertanggung jawab dalam penurunan laju korosi baja galvanis hingga 0,12 mpy pada waktu ekspos 76 hari.

\section{KESIMPULAN}

Kondisi lingkungan udara di daerah Pelabuhan Ratu memiliki kelembapan relatif yang tinggi, salinitas udara berkategori S1 dan perbedaan antara suhu udara dan suhu titik embun yang kecil saat malam bertendensi terjadinya reaksi elektrokimia pada baja galvanis. Reaksi elektrokimia tersebut dapat meningkatkan nilai laju korosi logam terhadap waktu ekspos. Kombinasi waktu basah dan kering bergantian ditandai dengan fluktuasi kelembapan udara dan suhu berkontribusi membuat lapisan protektif sehingga laju korosi menurun seiring waktu. Lapisan zincite dan hydrozincite dimana lapisan tersebut sangat protektif untuk ketahanan korosi. Beberapa metode mitigasi korosi pada baja galvanis antara lain penggantian material dengan baja lapis campuran Al-Zn-Si, penambahan ketebalan lapisan seng, dan perlindungan ganda melalui aplikasi pengecatan pada logam.

\section{UCAPAN TERIMA KASIH}

Kami mewakili para penulis mengucapkan terima kasih kepada rekan-rekan peneliti dan teknisi Pusat Penelitian Metalurgi dan Material-LIPI dalam penelitian lapangan di daerah Pelabuhan Ratu, Jawa Barat.

\section{DAFTAR PUSTAKA}

Association, American Galvanizers. 2010. "Technical Report: Performance of Hot-Dip Galvanized Steel Products."
Badea, G.E., P. Cret, M. Lolea, A.Setel. 2011. "Studies of Carbon Steel Corrosion in Atmospheric Conditions." Acta Technica Corviniensis-Bulletin of Engineering 4: 25-28.

Castro-Borges, P., Veleva, L. 2015. "No TitleTime of Wetness and HR-T Complex as Tools for Corrosion Risk Evaluation in a Concrete Block Exposed to a Humid Tropical Environment." Journal of Construction 14 (2): 65-71.

Feliu, S., Morcillo, M., Chico, B. 1999. "Effect of Distance from Sea on Atmospheric Corrosion Rate." Corrosion 55 (9): 883-91.

J.Langill., Thomas. 2003. "Predicting the Service Life of Galvanized Steel." 2003. https://www.thefabricator. com/article/metalsmaterials/predicting-the-service-life-of-galvanizedsteel.

Jaen, J.A., Iglesias, J., Hernandez, C. 2012. "Analysis of Short-Term Steel Corrosion Products Formed in Tropical Marine Environments of Panama." International Journal of Corrosion 2012: 1-11.

Jaen, J.A., Munoz, A., Justavino, J. 2009. "Characteriztion of Initial Atmospheric Corrosion of Conventional Weathering Steels and a Mild Steel in a Tropical Atmosphere." Journal Hyperfine Interactions 192 (1-3): 553-61.

Jenifer Alcántara, Daniel de la Fuente, Belén Chico, Joaquín Simancas, Iván Díaz and Manuel Morcillo. 2017. "Marine Atmospheric Corrosion of Carbon Steel: A Review." Materials 10 (406): 1-65.

John Onan Onyatta,Amir Okeyo Yusuf, Juspher Omondi Ooko. 2016. "Atmospheric Corrosion Studies in Kenya: Past, Present and Future." African Corrosion Journal 2 (1): 25-32.

Li, Z.W., Marston, N.J., Jones, M.S. 2013. "Update of New Zealand's Atmospheric Corrosivity Map, Branz Study Report SR.” 
Manuel Morcillo, Jenifer Alcántara, Iván Díaz, Belén Chico, Joaquín Simancas, Daniel de la Fuente. 2015. "Marine Atmospheric Corrosion of Carbon Steels." Revista De Metalurgia 51 (2): e045.

Md Mukhlesur Rahman, Mohitul Ameen Ahmed Mustafi, A.F.M.T. Islam, Nur Mohammad. 2015. "The Effect of Rainfall, Temperature and Humidity of Saline in The Southern Area of Bangladesh." Journal of Environment and Pollution Research 3 (1): $48-53$.

Nuraini, L., Prifiharni, S., Priyotomo, G., Sundjono, Gunawan, H., Purawiardi. 2018. "Atmospheric Corrosion Performance of Different Steels in Early Exposure in the Coastal Area Region West Java, Indonesia." In AIP Conference Proceedings 1964, 020040.

Revie, Winston. 2011. Uhlig's Corrosion Handbook. USA: John Wiley \& Sons, Inc.

Roberge, Pierre R. 1999. Handbook of Corrosion Engineering. New York: McGraw-Hill.
Rosa Vera, Fabián Guerrero, Diana Delgado, Raquel Araya. 2013. "Atmospheric Corrosion of Galvanized Steel and Precipitation Runoff from Zinc in a Marine Environment." Journal of the Brazilian Chemical Society 24 (3): 449-58.

Stephen R. Yeomans. 2004. Galvanized Steel Reinforcement in Concrete. Netherland: Elsevier B.V.

Subarna, Dadang. 2019. "Penentuan Zona Iklam Di Pulau Jawa Dan Mandura Menggunakan Sistem Informasi Geografi." 2019. https://www. academia.edu/11025358/Penentuan Zona_Iklim_di_Pulau_Jawa_dan_ Madura_Menggunakan_Sistem_Informasi Geografi .

Ubuoh E, Nwakanma C, Ogbuji S. 2017. "Atmospheric Corrosion of Corrugated Iron Roofing Sheet in Oil Producing Locations in Southeastern Nigeria." Journal of Enviromental \& Analytical Toxicology 7 (1): 1-6.

Y.W. Liu, Z.Y. Wang, G.W. Cao, Y. Cao, Y. Huo. 2017. "Study on Corrosion Behavior of Zinc Exposed in Coastal-Industrial Atmospheric Environment." Materials Chemistry and Physics 198: 243-49. 